\title{
Reconciling the Juridical Links Doctrine with the Federal Rules of Civil Procedure and Article III
}

\author{
William D. Henderson $\dagger$
}

Consider the following class action involving the cable television industry: Acme Cable, which provides service to all subscribers in Maintown, charges its customers a substantial late fee, which may amount to unenforceable liquidated damages. Other cable companies throughout the state levy similar or identical charges on their customers. ${ }^{1}$ After locating John Doe, an aggrieved resident of Maintown, an attorney initiates a class action on behalf of Doe and all other similarly situated parties against twenty-six cable operators throughout the state (Acme through Zydeco). Under the Federal Rules of Civil Procedure ("Federal Rules"), this litigation could take one of two forms: (1) using Rule 23, a plaintiff class of consumers could sue a defendant class of cable companies (a bilateral class action); ${ }^{2}$ or (2) a Rule 23 plaintiff class of consumers might individually join all twentysix defendants through Rule $20 .^{3}$

Because he has only been injured by Acme, Doe lacks a valid cause of action against the other twenty-five cable defendants. Doe may, however, escape this predicament. Although courts generally require that the class representative have a cause of action against each defendant, there are two exceptions to this requirement: "(1) Situations in which all injuries are the result of a conspiracy or concerted schemes between the defendants ... and (2) Instances in which all defendants are juridically related in a manner that suggests a single

$\dagger$ B.A. 1997, Case Western Reserve University; J.D. Candidate 2001, The University of Chicago.

1 This example is partially based on recent litigation in the cable industry. See TCI Cablevision of Dallas, Inc v Owens, 8 SW3d 837 (Tex App 2000); Beedle v Comcast SCH Holdings, Inc, No CL 98-5327 AG, slip op (Florida Cir Ct, Palm Beach County July 1, 1999). For ease of illustration, federal jurisdiction is assumed.

2 Under the Federal Rules, "One or more members of a class may sue or be sued as representative parties." FRCP 23(a) (emphasis added). Thus, the drafters of Rule 23 explicitly contemplated both plaintiff and defendant classes. A defendant class often requires a lower threshold number of parties. Herbert B. Newberg and Alba Conte, 1 Newberg on Class Actions $\$ 4.56$ at 4-215 to -216 (McGraw-Hill 3d ed 1992) (Under the Rule 23(a)(1) numerosity requirement, "[O]ne normally finds a higher threshold number of class members required for a plaintiff class than for a defendant class.").

3 A primary focus of this Comment is the interaction between Rule 23 and Rule 20(a) when a plaintiff class attempts to individually join multiple defendants. For the text of Rule 20 (a), see note 37 . 
resolution of the dispute would be expeditious." These two provisions are called, respectively, the "concerted action" and "juridical link" exceptions. Together they are commonly referred to as the "juridical links doctrine" ("doctrine").

Armed with both exceptions provided for under the doctrine, the plaintiffs' attorney could allege the presence of a juridical link based on an agreement among the companies to share production expenses or programming; ${ }^{6}$ reliance by the companies on regulatory filings made by a common trade association; ${ }^{7}$ or common ownership of the cable companies by a parent corporation. ${ }^{8}$ The attorney could also claim that the nearly identical terms of each consumer contract support an inference of conspiracy or concerted action. As a result, if the trial court determines that one or both of the exceptions have been met, Doe may be able to serve as a class representative in a lawsuit against defendant corporations Acme through Zydeco, despite only having a valid cause of action against Acme, his local cable operator.

Applied in this way, the juridical link and concerted action exceptions could dramatically alter the procedural balance between litigants by allowing one attorney, who has been spared the search costs of locating twenty-six class representatives, to direct the litigation strategy of a massive plaintiff class action against all twenty-six defendants. This litigation posture is essentially the aggregation of twenty-six separate class actions, each involving the same legal theory. If these class actions were litigated separately, the first case to be litigated on the merits (the test case) could inform the settlement structures for the remaining twenty-five cases. In fact, if the test case fails on the

4 Thompson $v$ Board of Education of Romeo Community Schools, 709 F2d 1200, 1204-05 (6th Cir 1983) (emphasis added). See also Haas v Pittsburgh National Bank, 526 F2d 1083, 1088 n 3 (3d Cir 1975), citing La Mar v H \& B Novelty and Loan Co, 489 F2d 461, 466 (9th Cir 1973); Erie Fire Insurance Co v Madden, 204 W Va 606, 515 SE2d 351, 354 (1998).

5 To clarify, this Comment will use "link" (singular) when referring to the juridical link exception and "links" (plural) when referring to the juridical links doctrine as a whole, which includes both the concerted action exception and juridical link exception.

6 Consider Endo v Albertine, 147 FRD 164,172 (N D Ill 1993) (observing that the defendant class of underwriters is arguably juridically linked through an expense-sharing agreement among the underwriters); United States $v$ Trucking Employers, Inc, 75 FRD 682, 689-90 (D DC 1977) (holding that trucking employers in a Title VII class action are juridically linked by an industry-wide collective bargaining agreement).

7 See Heffler $v$ United States Fidelity \& Guaranty Insurance Co, 1992 US Dist LEXIS $3090, * 11$ (E D Pa) (concluding that common form provided by an industry trade group was a valid juridical link).

8 See, for example, Barker v FSC Securities Corp, 133 FRD 548, 553 (W D Ark 1989) (holding that common corporate ownership is a valid juridical link); Texas Commerce Bank National Association $v$ Wood, 994 SW2d 796, 807 (Tex App 1999) (same).

(9) Consider Bromley v Michigan Education Association-NEA, 178 FRD 148, 163 (E D Mich 1998) (using both exceptions to join teachers' unions that shared national affiliation and a common method of calculating service fees); Beedle, No CL 98-5327 AG, slip op at 4 (applying both exceptions to subsidiaries of a cable television holding company). 
merits, the expected value of the remaining twenty-five class actions is near zero. Yet, by pleading either the concerted action or juridical link exceptions, a plaintiffs' attorney could potentially force all defendants into one lawsuit. ${ }^{10}$ As a result, a single plaintiffs' attorney can perpetuate uncertainty among the defendants by withholding an initial test case. This strategy increases the attorney's settlement leverage (and his expected contingency fee).

The doctrine's two judge-made exceptions allow suit when the class representative lacks a cause of action against each defendant, as the term is customarily understood. The case law is not clear, however, whether the concerted action and juridical link doctrines are exceptions to standing" or to the class action requirements of the Federal Rules that govern the formation of both plaintiff and defendant classes. ${ }^{12}$ Yet, if this powerful litigation posture is to be justified, it must be reconciled with both the jurisdictional requirement of Article III standing and the procedural requirements set forth in the Federal Rules.

The lack of a coherent legal framework for analyzing multiple defendant class actions has resulted in an unwarranted expansion of the doctrine. Most courts that have applied the doctrine's two exceptions have emphasized the efficiency benefits of adjudicating similar disputes in one legal proceeding, yet these courts have failed to consider the limitations imposed by the Rules Enabling Act, ${ }^{13}$ which prohibits the Federal Rules from "abridg[ing], enlarg[ing] or modify[ing] any substantive right, ${ }^{14}$ and Rule 82, which forbids the Federal Rules from "extend[ing] or limit[ing] the jurisdiction of the United States district courts." This tendency is most acute in Rule 23(b)(3) class actions, where the court has applied the doctrine without considering any distinction between a Rule 23 defendant class and defendants individu-

10 A plaintiffs' attorney accomplishes this objective by avoiding defendant class certification under Rule 23(b)(3), which permits unnamed defendants to exit the class, see notes 33-35 and accompanying text, in favor of defendant class certification under Rule 23(b)(2) or individual joinder under Rule 20(a). The legality of both of these strategies is challenged in Parts II.B and II.C. Background procedural issues are discussed in Part I.A.

11 See Bromley, 178 FRD at 162-63 (construing juridical links doctrine as an exception to the standing requirement); Kohn v Mucia, 776 F Supp 348, 354-55 (N D Ill 1991) ("[J]uridical link doctrine essentially confers the standing of each individual class member on the class representative.").

12 See Leer v Washington Education Association, 172 FRD 439, 447 (W D Wash 1997) (construing juridical links doctrine as an exception to the Rule 23(a)(3) typicality requirement); Doe v Spokane and Inland Empire Blood Bank, 55 Wash App 106, 780 P2d 853, 860 n 6 (1989) ("[Unless] there is a juridical link among the defendants, the class representative's claim cannot possibly satisfy the typicality requirement.").

1328 USC \& 2072(b) (1994).

14 Id.

15 FRCP 82. 
ally joined under Rule 20 (a). ${ }^{16}$ In the latter context, courts have used both the juridical link and concerted action exceptions as a freestanding joinder device that rarely considers the requirements of Rule 20(a).

Drawing on two recent Supreme Court decisions on class actions, Ortiz v Fibreboard Corp ${ }^{17}$ and Amchem Products, Inc $v$ Windsor, ${ }^{18}$ this Comment sets forth a clear framework for analyzing multiple defendant class actions. First, both of these recent precedents have stated that issues of class certification are "logically antecedent" to concerns related to Article III. ${ }^{19}$ Therefore, a multiple defendant class action must first satisfy the provisions of Rule 23, and by extension, Rule 20, before turning to the requirement of standing under Article III. Second, both Ortiz and Amchem mandate a textual interpretation of the Federal Rules in order to preserve the careful balance of judicial policymaking and procedural fairness that the language of the Rules is designed to embody. Thus, the doctrine's application to defendant classes under Rule 23 and individually joined defendants under Rule 20 needs to be examined under this more rigorous jurisprudence.

Applying this two-part framework, this Comment attempts to set forth the proper scope and application of the juridical link and concerted action exceptions. Part I examines the origins of the juridical links doctrine and its subsequent applications. Part II focuses on three tension points within the doctrine. First, it explores the uncertainty over whether the doctrine is an exception to the requirements of Rule 23 or to Article III standing. Second, it examines the emergence of a more textual approach to the Federal Rules, which has sharply undercut injunctive relief against a defendant class-the most established application of the juridical links doctrine. ${ }^{21}$ It also analyzes the application of the doctrine to defendants individually joined under Rule 20.

16 Compare Samuel M. Shafner, Note, The Juridical Links Exception to the Typicality Requirement in Multiple Defendant Class Actions: The Relationship between Standing and Typicality, 58 BU L Rev 492, 493 n 7 (1978) ("[I]t is immaterial whether the multiple defendants are joined in accordance with rule 20(a) or are members of a class under rule 23.").

17527 US 815 (1999)

18521 US 591 (1997).

19 Ortiz, 527 US at 831 ("Class certification issues are, as they were in Amchem, 'logically antecedent' to Article III concerns and themselves pertain to statutory standing, which may properly be treated before Article III standing.") (citations omitted); Amchem, 521 US at 612-13 (determining that resolution of class certification issues are "logically antecedent" to Article III issues). Courts and commentators have often assumed the reverse. See note 90.

20 See Ortiz, 527 US at 858-59 (criticizing the lower courts for ignoring text of Rule 23 and thus undermining safeguards built into the rule); Amchem, 521 US at 620 (stating that careful balance of judicial policymaking in the drafting and adoption of the Federal Rules "limits judicial inventiveness").

21 The emerging view is that "the party opposing the class" language of Rule 23(b)(2) does not contemplate a defendant class opposing a plaintiff class. See text accompanying notes 98106. 
Finally, Part II highlights how the current state of the doctrine works to the benefit of plaintiffs' attorneys while undermining procedural fairness for defendants.

Part III then proposes that courts follow a more limited version of the doctrine that applies the exceptions only to Rule 23(b)(3) defendant classes, which are protected by a mandatory opt out provision for plaintiff and defendant class members. In this narrow category of cases, the doctrine may survive scrutiny under Article III while also serving the policy objectives of judicial economy and private law enforcement that underlie the class action device. ${ }^{2}$ However, in the majority of cases, the juridical links doctrine cannot be reconciled with a careful application of the Federal Rules, and courts, therefore, should limit the doctrine's use.

\section{ORIGIN AND APPLICATIONS OFTHE JURIDICAL LINKS DOCTRINE}

This Part first discusses Federal Rule 23 and the options it presents to potential plaintiff classes. This Part then examines some of the historical and legal factors that gave rise to the juridical link and concerted action exceptions and finally discusses three distinct types of cases that have evolved through their application.

\section{A. Multiple Defendant Class Actions under Rule 23 and Rule 20}

Imagine once again Doe's lawsuit against the cable industry. In order to bring a class action lawsuit under the Federal Rules, Doe and the proposed plaintiff class must satisfy the four mandatory criteria of

22 See Diane Wood Hutchinson, Class Actions: Joinder or Representational Device, 1983 S Ct Rev 459, 480 (1984) (arguing that the Court's decisions on class actions evidence two policy objectives, "one favoring efficiency and economy of litigation, and one emphasizing the role of the class action as a supplement to public law enforcement efforts").

23 Although this Comment will rely only on the Federal Rules of Civil Procedure, its analysis is meant to extend to their equivalents on the state level. Most states have adopted rules that are modeled on their federal counterpart. Thus, interpretations of the Federal Rules often serve as persuasive authority in state court. See, for example, Intratex Gas Co v Beeson, 2000 Tex LEXIS 23, *10 n 4 ("[Texas] Rule 42 is based on its federal counterpart, Federal Rule of Civil Procedure 23. Cases interpreting the federal rule are persuasive authority."); Perry v Gallaudet University, 738 A2d 1222, 1226 (DC 1999) ("Interpretations of federal rules identical to our rules are accepted as persuasive authority."); Turnbull v Horan, 522 NW2d 860,861 (Iowa App 1994) (noting that federal case law interpreting similar rules of procedure "constitutes persuasive authority"). Moreover, many states have either a constitutional or statutory analogue to the Rules Enabling Act, 28 USC \$ 2072(b). See, for example, Ala Const Amend 328, § 6.11 (A procedural or administrative rule may not "abridge, enlarge or modify the substantive right of any party" nor "affect the jurisdiction of circuit and district courts."); Tex Government Code Ann $\$ 22.004$ (a) (Vernon 1988) (granting the Texas Supreme Court the authority to make rules of procedure, "except that its rules may not abridge, enlarge, or modify the substantive rights of a litigant"). 
Rule 23(a): (1) numerosity, (2) commonality, (3) typicality, and (4) adequacy of representation.

In the situation posed here, we can assume that plaintiff Doe can easily satisfy all four Rule 23(a) criteria in a class action maintained just against Acme Corporation. However, the application of the juridical links doctrine poses the additional issue of whether Doe can meet the Rule 23(a) criteria as a class representative against defendants Beta through Zydeco, even though he lacks an independent cause of action against them. With claims against all twenty-six cable companies that involve identical legal theories, and virtually no factual variation among plaintiffs, the case law on Rule 23(a) is very susceptible to an extension that would permit multiple defendants. ${ }^{25}$ Thus, in order to curtail the massive expansion of multiple defendant class actions, courts have interpreted the Rule 23(a)(3) typicality requirement as mandating that the representative plaintiff possess a cause of action against each defendant. ${ }^{26}$ It is this interpretation of typicality, though sometimes stated in terms of Article III standing, that the doctrine's two exceptions are meant to operate against.

If the four Rule 23(a) factors are present-perhaps through the aid of either the concerted action or juridical link exception-the proposed plaintiff class must then satisfy one of three categories of class actions under Rule 23(b). Rule 23(b)(1) permits class certification when separate proceedings would either "establish incompatible stan-

24 FRCP 23(a)(1)-(4).

25 Considered individually, the Rule 23 (a) requirements of commonality, typicality, and adequacy of representation set relatively low hurdles for the potential class representative. See, for example, Stewart $v$ Winter, 669 F2d 328, 335 (5th Cir 1982) (holding that commonality requires "that there be at least one issue whose resolution will affect all or a significant number of the putative class members"); Alpern v Utilicorp United, Inc, 84 F3d 1525, 1540 (8th Cir 1996), quoting DeBoer v Mellon Mortgage Co, 64 F3d 1171, 1174 (8th Cir 1995) (concluding that the typicality burden is "fairly easily met so long as other class members have claims similar to the named plaintiffs"); Margolis v Caterpillar, Inc, 815 F Supp 1150, 1157 (C D Ill 1991) ("The adequacy requirement of Rule 23(a)(4) consists of two components: (1) the absence of a potential conflict between the named plaintiffs and the absent class members; and (2) that the parties' attorneys be qualified, experienced, and generally able to conduct the proposed litigation.").

26 La Mar v H \& B Novelty \& Loan Co, 489 F2d 461, 465 (9th Cir 1973) (ruling that typicality is "lacking when the plaintiffs' cause of action, although similar to that of other members of the class, is against a defendant with respect to whom the class members have no cause of action" and observing that "restrictions on the flexible language of Rule 23 are a necessary contribution to the effort to avoid the intractable problems of massive class actions"); Cedar Crest Funeral Home, Inc y Lashley, 889 SW2d 325, 332 (Tex App 1993) ("A representative plaintiff's claim is not 'typical' ... when the representative has no cause of action against one or more of the defendants sued by the class"); Streich v American Family Mutual Insurance Co, 399 NW2d 210,215-16 (Minn App 1987) (adopting La Mar rule on typicality).

27 See, for example, Haas v Pittsburgh National Bank, 526 F2d 1083, 1095, 1096 n 15 (3d Cir 1975) (ruling that if "no nominal plaintiff has standing on any issue against one of multiple defendants, a suit for damages may not be maintained as a class action against that defendant" and noting that the rule has been stated in terms of both standing and Rule 23(a)(3) typicality). 
dards of conduct for the party opposing the class" ${ }^{28}$ (usually the defendant) or "substantially impair or impede" the rights and interests of parties not before the court. ${ }^{29}$ Because of its narrow focus and language, which seems to contemplate a jointly held right or obligation among the litigants, ${ }^{30}$ Rule 23(b)(1) has generally not been amenable to defendant class actions. As a result, the doctrine has primarily been limited to class actions certified under subsections (b)(2) and (b)(3).

Under Rule 23(b)(2), the class representative can request declaratory or injunctive relief against conduct or a practice that generally affects all members of the proposed class. ${ }^{32}$ For example, plaintiff Doe could request that Acme through Zydeco be enjoined from levying excessive late fees on its customers.

In contrast, Rule 23(b)(3) allows a class to adjudicate monetary claims where common issues predominate..$^{33}$ Thus, under 23(b)(3), Doe's plaintiff class could also seek to recover several years of late fees. Though 23(b)(3) is broad enough to facilitate many more cases than the other 23(b) provisions, a 23(b)(3) class action also triggers subsection (c)(2), which requires that potential class members be notified of the lawsuit and given the opportunity to opt out of the class. ${ }^{34}$ These features are necessary in order to safeguard the constitutional due process rights of the potential members of the plaintiff class.

28 FRCP 23(b)(1)(A). The Advisory Committee's Note gives the example of litigating the rights and duties of riparian owners or landowners responding to a claimed nuisance, where separate court proceedings could order incompatible conduct. See Proposed Rules of Civil Procedure, 39 FRD 69,100 (1966).

29 FRCP 23(b)(1)(B). The Advisory Committee's Note discusses the example of a fund that would be insufficient to pay all the claims arising from numerous separate lawsuits. See Proposed Rules, $39 \mathrm{FRD}$ at 101 (cited in note 28 ).

30 Henson v East Lincoln Township, 814 F2d 410, 412-13 (7th Cir 1987) (using the 1966 Advisory Committee's Note to determine the limitations of 23(b)(1) for defendant classes).

31 This limitation is examined in Part III.A.3.

32 Rule 23(b)(2) provides:

An action may be maintained as a class action if the prerequisites of subdivision (a) are satisfied, and in addition ... the party opposing the class has acted or refused to act on grounds generally applicable to the class, thereby making appropriate final injunctive relief or corresponding declaratory relief with respect to the class as a whole.

33 FRCP 23(b)(3).

34 FRCP 23(c)(2) provides, in part:

In any class action maintained under subdivision (b)(3), the court shall direct to the members of the class the best notice practicable under the circumstances, including individual notice to all members who can be identified through reasonable effort. The notice shall advise each member that $(A)$ the court"will exclude the member from the class if the member so requests by a specified date.

35 See, for example, Ortiz, 527 US at 845-46 (summarizing previous cases that demonstrate that notice and opportunity to opt out are due process requirements); Phillips Petroleum Co $v$ Shutts, 472 US 797, 811-12 (1985) (ruling that a plaintiff class member in state court has a constitutional right to notice and opt out when claims primarily involve monetary judgments). 
Rule 23's requirements apply equally to a suit against a class of defendants. Since there are twenty-six cable company defendants, Doe's attorney faces two options for bringing the defendants into this litigation. He either could (1) request a 23(b)(2) or 23(b)(3) defendant class, in which case a defendant class representative must also satisfy the requirements of Rule $23(\mathrm{a})^{36}$ or (2) individually join each defendant through the permissive joinder requirements of Rule 20 (a). ${ }^{37}$

In the event that Doe's counsel pursues a 23(b)(3) defendant class, the defendant class operates under the same rules as the 23(b)(3) plaintiff class: unnamed members possess "an absolute right to opt out of the class." ${ }^{38}$ This strategy would create a bilateral class action in which the plaintiffs and their attorney run the risk of all or most of the defendants opting out of the defendant class. A plaintiffs' attorney seeking damages, therefore, has a strong incentive to reject the bilateral class action and, instead, to join each defendant (Acme through Zydeco) individually.

Like the class action device, permissive joinder under Rule 20(a) is designed to promote judicial economy by "reduc[ing] inconvenience, delay, and additional expense." ${ }^{39}$ Yet, returning to our example, the central question posed by the juridical links doctrine is whether a representative plaintiff such as Doe, who lacks a cause of action against the defendants Beta through Zydeco, can nevertheless comply with the requirements of Rule 20(a) and join the defendants in a single lawsuit for monetary damages. The following Sections examine the case law and then this central issue is addressed in Part II.

\section{B. Origin of the Juridical Link and Concerted Action Exceptions}

La Mar v $H \& B$ Novelty \& Loan $\mathrm{Co}^{40}$ was the first case to articulate the juridical links doctrine." In $L a M a r$, the representative plaintiffs, who lacked a cause of action against each defendant, alleged

36 For an extensive examination of defendant classes, including their requirements, applications, and history, see Newberg and Conte, 1 Newberg on Class Actions $\$ \$ 4.45-4.66$ (cited in note 2).

37 FRCP 20(a) provides:

All persons ... may be joined in one action as defendants if there is asserted against them jointly, severally, or in the alternative, any right to relief in respect of or arising out of the same transaction, occurrence, or series of transactions or occurrences and if any question of law or fact common to all defendants will arise in the action.

38 Mudd v Busse, 68 FRD 522, 530 (N D Ind 1975).

39 Coughlin v Rogers, 130 F3d 1348, 1351 (9th Cir 1997), citing Guedry v Marino, 164 FRD 181,184 (E D La 1995).

$40 \quad 489$ F2d 461 (9th Cir 1973).

41 See Shafner, Note, 58 BU L Rev at 492-93 (cited in note 16) (attributing two exceptions to dicta found in La Mar). 
a common method of injury to unite otherwise unrelated defendants. ${ }^{42}$ Aware that the proposed litigation could open the door to massive lawsuits covering entire industries, the court referred to the Advisory Committee's Note for the recently revised Rule 23 . $^{43}$ The court observed: "[T]here is nothing in the Advisory Committee's Note that suggests that the amendments had as their purpose the authorization of massive class actions conducted by attorneys engaged by nearnominal plaintiffs." The La Mar court held that a class representative "cannot represent those having causes of action against other defendants against whom the plaintiff has no cause of action and from whose hands he suffered no injury."

In the process of rejecting the plaintiffs' suit, the court recognized two exceptions to this general rule to distinguish several civil rights cases that had permitted multiple defendant class actions where the named plaintiffs lacked a cause of action against each defendant. ${ }^{46}$ In discussing the concerted action exception, the court distinguished Contract Buyers League v F\& F Investment, ${ }^{47}$ in which the defendants had allegedly engaged in a concerted pattern of discrimination against black home buyers throughout Chicago. Under the juridical link exception, the Ninth Circuit distinguished Washington v Lee, ${ }^{49}$ a class action by black inmates against the segregation policies utilized by jailers throughout the state of Alabama. According to the court, the fact that "all the defendants were officials of a single state and its subordinate units of government" linked them in a way that the defendants in La Mar were not."

Although both of the doctrine's two exceptions were first articulated as dicta in $L a M a r$, subsequent courts invariably relied upon them as a guide for analyzing multiple defendant class actions. Part I.C will now examine the case law in the aftermath of La Mar.

42 La Mar was the consolidation of two cases. First, the plaintiff dealt with only one pawnbroker but alleged similar violations of the Truth in Lending Act by other pawnbrokers throughout the state of Oregon. See La Mar, 55 FRD 22 (D Or 1972), revd, 489 F2d 463 (9th Cir 1973). In the other case, the lead plaintiff alleged fare overcharges by eight airlines in violation of the Federal Aviation Act, although he had personally dealt with only two of the defendants. See La Mar, 489 F2d at 463 .

43 See Proposed Rules, 39 FRD at 103 (cited in note 28).

$44 \mathrm{La} \mathrm{Mar}, 489 \mathrm{~F} 2 \mathrm{~d}$ at 465.

45 Id at 462.

46 Id at 469-70.

47300 F Supp 210 (N D Ill 1969).

48 Id at 213-14.

49263 F Supp 327 (M D Ala 1966).

50 Id at 328-29.

51 La Mar, 489 F2d at 470. La Mar also distinguished Broughton v Brewer, 298 F Supp 260 (N D Ala 1969) (class action challenging Alabama's vagrancy laws). See $489 \mathrm{~F} 2 \mathrm{~d}$ at 470. 
C. Application of the Juridical Link and Concerted Action Exceptions

1. The juridical link exception.

The use of the juridical link exception has evolved over time. Initially, the exception incorporated only government defendants. Eventually, it was extended to private actors who were connected by a common agreement or uniform practice. This emphasis on a uniformly enforced rule or agreement has since given way to a broader exception guided by judicial efficiency.

a) Juridical link among government defendants. Following La Mar, the initial applications of the juridical links doctrine all involved plaintiffs seeking to certify a group of government officials as a 23(b)(2) defendant class. Many courts have interpreted the paradigm juridical link application as a situation "where all members of the defendant class are officials of a single state and are charged with enforcing or uniformly acting in accordance with a state statute, or common rule or practice of state-wide application, which is alleged to be unconstitutional.",

For example, in DeAllaume $v$ Perales, ${ }^{53}$ welfare recipients in New York state initiated a class action in order to challenge a common method of calculating heating subsidies for persons receiving both state and federal relief payments. ${ }^{\text {s4 }}$ The plaintiffs requested declaratory and injunctive relief against a 23(b)(2) defendant class of all fifty-eight county commissioners in the state, who were allegedly implementing the same unlawful policy pursuant to an administrative order. Although the representative plaintiff did not have a colorable claim against each defendant, the court granted certification because "a unified policy link[ed] the members of the proposed defendant class," and the requirements of Rule 23 had otherwise been satisfied. ${ }^{\text {ss }}$ In DeAllaume, as in other juridical links cases involving government officials, the defendants lacked individual discretion in implementing the con-

52 DeAllaume v Perales, 110 FRD 299, 303 (S D NY 1986), quoting Mudd v Busse, 68 FRD 522, 527-28 (N D Ind 1975). See also Leer v Washington Education Association, 172 FRD 439, 448 (W D Wash 1997); Turpeau v Fidelity Financial Services, Inc, 936 F Supp 975, 978 (N D Ga 1996), affd, 112 F3d 1173 (11th Cir 1997).

53110 FRD 299 (S D NY 1986).

54 Id at 302.

55 Id at 304-07. See also Monaco v Stone, 187 FRD 50, 53-54, 66 (E D NY 1999) (permitting defendant class of judges in order to challenge statute that detains mentally ill patients after dismissal of criminal charges); Hopson $v$ Schilling, 418 F Supp 1223, 1237-38 (N D Ind 1976) (certifying defendant class of township trustees in dispute over the administration of welfare relief). 
tested rule or statute, thus standardizing the factual underpinnings of each case.

b) Juridical link among private sector defendants. The juridical links doctrine was eventually extended to cases involving nongovernmental defendants. Given the case law's emphasis that a valid juridical link requires a uniformly enforced rule or policy, the doctrine has been applied to employment discrimination class actions against private employers who were connected through an industry-wide collective bargaining agreement" and insurance companies that relied on the regulatory filings of a common trade association. $\$$ The doctrine has also been used to join individual corporations that at one time shared a common corporate ownership.

Another area that has been particularly amenable to an expansion of the juridical link exception is federal securities litigation, usually taking the form of Rule 23(b) bilateral class actions. For example, In re Computer Memories Securities Litigation ${ }^{60}$ involved a 23(b)(3) defendant class of underwriters that had allegedly made misrepresentations in the prospectus and registration statement of an initial public offering of stock. . $^{1}$ Because Section 12(2) of the Securities Act of 1933 allows recovery only from defendants that substantially participate in the sale of a plaintiff's stock, the court observed that the named plaintiff would not have standing to sue each underwriter individually. However, the defendants had each entered into a common agreement

56 See, for example, Thompson v Board of Education of Romeo Community Schools, 709 F2d 1200, 1205 (6th Cir 1983) (finding no juridical link in Title VII class action challenging individual school board maternity leave policies because each defendant could set its own policy).

57 See, for example, Marchwinski v Oliver Tyrone Corp, 81 FRD 487, 489 (W D Pa 1979) (finding employers juridically related by a union contract); United States v Trucking Employers, Inc, 75 FRD 682, 689-90 (D DC 1977) (finding that agreements "serve a function analogous to that served by the statutes" in government cases).

58 Heffler v United States Fidelity \& Guaranty Insurance Co, 1992 US Dist LEXIS 3090, *11 (E D Pa) (concluding that a common form provided to regulators by industry trade group was valid juridical link but failing to certify on adequacy grounds).

59 See Barker v FSC Securities Corp, 133 FRD 548, 550-53 (W D Ark 1989) (joining two corporations in a class action involving breach of contract and conversion; applying juridical link exception because both defendants were subsidiaries of the same parent corporation for four of the twelve years in which the plaintiff class members were allegedly injured). Relying on Barker, state courts have recently held common ownership to be a valid juridical link. See, for example, TCI Cablevision of Dallas, Inc v Owens, 8 SW3d 837, 843 (Tex App 2000); Beedle v Comcast SCH Holdings, Inc, No CL 98-5327 AG, slip op at 4 (Fla Cir Ct, Palm Beach County July 1, 1999).

60111 FRD 675 (N D Cal 1986).

61 Id at 678-79.

62 Id at 681 . Juridical link cases involving securities usually include claims under $\$ 11$ and $\S 12$ (2) of the Securities Act of 1933, Pub L No 73-22, 48 Stat 74, 82-84, codified at 15 USC $\S \S 77 \mathrm{k}, 77 \mathrm{l}(\mathrm{a})(2)(1994)$. Only $\S 12(2)$ claims require a juridical link to join defendants. Section 11 makes all underwriters jointly liable for a material misrepresentation during a public offering, "thereby eliminating any La Mar problem." In re Gap Stores Securities Litigation, 79 FRD 283, 298 (N D Cal 1978). 
on matters pertaining to the underwriting process. Thus, the court found that they were "bound to a common course of conduct for purposes of the [securities] offering," and the juridical link exception therefore applied. ${ }^{63}$

Juridical link cases involving securities are also noteworthy because they routinely involve a 23(b)(3) defendant class, which allows all unnamed defendants to exit the class through the Rule 23(c)(2) opt out provision. ${ }^{4}$ Since an absent defendant could be potentially liable for monetary damages, courts have often viewed the 23(c)(2) opt out as a due process safeguard that makes defendant class certification possible.

c) Juridical link to achieve judicial efficiency. Over time, the juridical link exception's focus on a uniformly enforced rule or agreement has gradually been supplanted by a more general emphasis on judicial efficiency. This trend has been especially true in the context of individually named defendants. For example, in Weiss $v$ Winner's Circle of Chicago, Inc, ${ }^{66}$ a Rule 23(b)(3) plaintiff class joined three defendants under Rule 20 because they had provided financing to consumers through another defendant, who had utilized fraudulent sales practices. ${ }^{67}$ Although the named plaintiff had no cause of action with regard to two of the defendants, the court applied the juridical links exception because "it would be expeditious to allow the Lender defendants to be joined and obtain a single resolution.","

The expansion of the juridical link exception may also have been fueled by the lack of any clear definition for "juridical link." For example, in the recent case of Monaco $v$ Stone, ${ }^{69}$ the court defined a juridical link as a "legal relationship which relates all defendants in a way such that a single resolution of the dispute is preferred to a multiplicity of similar actions." ${ }^{, 70}$ Similarly, in Bromley $v$ Michigan Education Association-NEA," the court applied the juridical link exception be-

63 Computer Memories, 111 FRD at 681. See also Endo v Albertine, 147 FRD 164, 172 (N D IIl 1993) (finding a juridical link via an agreement containing certain indemnity and expense sharing clauses); In re Activision Securities Litigation, 621 F Supp 415, 432 (N D Cal 1985) (same).

64 See notes 34-35 and accompanying text.

65 Endo, 147 FRD at 172 (noting that because of opt out, "due process concerns do not defeat defendant class certification"); Henson v East Lincoln Township, 108 FRD 107, 111 (C D Ill 1985) (contrasting the opt out provision under $23(\mathrm{~b})(3)$-which mitigates due process concerns - with no opt out under 23(b)(2)).

661995 US Dist LEXIS 18713 (ND III).

67 Id at $* 10$.

68 Id at *6.

69187 FRD 50 (E D NY 1999).

70 Id at 65-66, quoting Luyando v Bowen, 124 FRD 52, 58 (S D NY 1989). See also Leer, * 172 FRD at 447 (same).

71 178 FRD 148 (E D Mich 1998). 
cause "all defendants are juridically related in a manner that suggests a single resolution of the dispute would be expeditious."

A related problem within the case law is the failure of courts to recognize potential differences between multiple defendant class actions that involve a defendant class versus individually joined defendants. In the first years after the La Mar decision in 1973, all of the cases that applied the juridical link exception involved defendant classes under Rule 23. During the last decade, however, several courts have uncritically extended this exception to cases involving individually named defendants. In each of these decisions, the court has acknowledged that the representative plaintiff lacks a valid cause of action against each individually named defendant, yet the permissibility of joinder is analyzed primarily in terms of the juridical link exception rather than the permissive joinder requirements of Rule 20(a).

The summary treatment given to Rule 20(a) may be attributable to the policy of judicial economy and avoidance of multiple trials, which has traditionally encouraged courts to liberally construe the permissive joinder requirements. ${ }^{74}$ Yet the resulting litigation posture is a multiple defendant class action in which the named plaintiff lacks a valid cause of action against each defendant. Not surprisingly, several courts that have relied on the doctrine as a basis for permitting joinder have also described it as an "exception to the standing requirement" rather than the Rule 23(a)(3) typicality requirement.

\section{The concerted action/conspiracy exception.}

The concerted action exception is a relatively narrow category that has been applied in a handful of contexts in which a conspiracy or a concerted scheme among defendants would not necessarily result in

72 Id at 163, quoting Thompson, 709 F2d at 1204-05 (emphasis omitted). See also Cedar Crest Funeral Home, Inc v Lashley, 889 SW2d 325, 331 (Tex App 1993) (using similar language from La Mar).

73 See, for example, Bromley, 178 FRD at 163 (using both exceptions to join eight teachers' unions without any discussion of Rule 20); Weiss, 1995 US Dist LEXIS 18713 at *5-6 (using juridical link exception in a consumer sales class action in order to overcome lack of privity between the named plaintiff and three defendants); Barker, 133 FRD at 553 (using a juridical link, without any discussion of Rule 20 , to join two corporate defendants that had earlier been owned by same parent corporation).

74 See, for example, United Mine Workers of America v Gibbs, 383 US 715, 724 (1966) ("Under the Rules, the impulse is toward entertaining the broadest possible scope of action consistent with fairness to the parties; joinder of claims, parties and remedies is strongly encouraged."); League to Save Lake Tahoe v Tahoe Regional Planning Agency, 558 F2d 914, 917 (9th Cir 1977) (" $[\mathrm{P}]$ ermissive joinder [under Rule 20(a)] is to be construed liberally in order to promote trial convenience and to expedite the final determination of disputes, thereby preventing multiple lawsuits.").

75 Weiss, 1995 US Dist LEXIS at *5. See also Bromley, 178 FRD at 162-63 (analyzing both concerted action and juridical link as exceptions to the standing requirement); Beedle, No CL 98$5327 \mathrm{AG}$, slip op at 3 (referring to doctrine as "exception to the standing requirement"). 
joint or vicarious liability. For example, in Roberts $v$ Heim ${ }^{76}$ plaintiffs were investors in allegedly fraudulent limited partnerships that had been set up by several general partners." Although the representative plaintiffs had only invested in four partnerships, they sought to represent injured plaintiffs in a total of forty different ventures, which, in turn, implicated a wider array of defendants. ${ }^{78}$ Because the defendants' conduct was covered by the concerted action exception, the court certified the plaintiff class action even though the representative plaintiffs did not have a claim against each defendant."

In class actions in which liability is limited by privity requirements or statute, courts have struggled to distinguish the concerted action exception from general claims of fraud or illegal conspiracy. For example, in Hudson v Capital Management International, Inc, plaintiffs attempted to litigate Section 12(2) securities claims against a broad array of defendants. ${ }^{81}$ Noting that Section 12(2) limits liability to parties who were a substantial factor in causing the sale of stock, the court observed:

The concerted scheme theory is an extension of the conspiracy exception, which is really not an exception at all. A conspiracy allegation states a claim against all conspirators. Similarly, in a fraud claim, a concerted scheme or aiding or abetting allegation actually states a claim against all defendants. Liability under $\S 12$ is expressly limited, however, and is not susceptible to such extension.

76670 F Supp 1466 (N D Cal 1987), revd in part on other grounds as Roberts v Peat, Marwick, Mitchell \& Co,857 F2d 646 (9th Cir 1988).

$77670 \mathrm{~F}$ Supp at 1473.

78 Id at 1490 .

79 Id at $1490-91$.

801982 US Dist LEXIS 10071 (N D Cal).

81 Id at *7.

82 Id at *12-13. See also Cedar Crest Funeral Home, Inc v Lashley, 889 SW2d 325, 331 (Tex App 1993) (refusing to join individual defendants on typicality grounds because conspiracy exception requires joint and several liability). Generally, a charge of conspiracy or concerted action that involves an underlying contract dispute rather than a tort is unlikely to establish a cause of action against each alleged co-conspirator. See, for example, In re Orthopedic Bone Screw Products Liability Litigation, 193 F3d 781, 789 \& n 7 (3d Cir 1999) (surveying state law in a multidistrict litigation case and concluding that "a cause of action for civil conspiracy [uniformly] requires a separate underlying tort as a predicate for liability"). Yet, at the state level, courts have been divided over whether the concerted action exception can be applied when the underlying dispute involves contract rather than tort law. Compare Burnham Service Corp v National Council of Compensation Insurance, Inc, NY L J 23 (July 30, 1999) (NY Sup Ct, NY County) (rejecting concerted action exception in dispute involving private workers' compensation insurance because underlying claims involved contract law), with Beedle v Comcast SCH Holdings, Inc, No CL 98-5327 AG, slip op at 4 (Fla Cir Ct, Palm Beach County July 1, 1999) (holding that similar consumer contracts of various cable subsidiaries satisfies concerted action exception). Courts have since clarified that defendants in an antitrust conspiracy are subject to both treble damages 
Finally, the concerted action exception has been used in private antitrust litigation involving multiple defendants. In an antitrust conspiracy, the injured parties have a cause of action against each coconspirator. ${ }^{83}$ Therefore, this exception has been more narrowly applied to the Rule 23(a)(3) typicality problem in certifying a plaintiff class, which arises when the representative plaintiffs have had no dealings with many of the defendants.

\section{PROBLEMS WITH THE EXCEPTIONS}

As courts have applied the juridical link and concerted action exceptions, no coherent framework has emerged for analyzing multiple defendant class actions. Before courts can distill the juridical links case law into a useful and discrete legal doctrine, three problems must first be addressed.

First, the juridical links doctrine has been described as both an exception to the Rule 23(a)(3) typicality requirement and an exception to Article III standing. This uncertainty has led to a confusing merger of procedural and jurisdictional issues and has hindered the ability of courts to define and limit the doctrine's proper application.

Second, many of the cases involving the juridical links doctrine cannot be reconciled with a careful reading and application of the Federal Rules. A more textual interpretation of Rule 23(b)(2) has sharply undercut the most accepted application of the doctrine involving defendant classes. Moreover, in the context of individually joined defendants, most courts have simply failed to consider the Rule 20(a) requirements for permissive joinder.

Third, any perceived benefits of judicial economy derived from the juridical links doctrine must be weighed against the potential for procedural imbalance between plaintiffs and defendants. A broad application of the doctrine is likely to enhance the settlement leverage of plaintiffs' attorneys without any corresponding increase in private law

and joint and several liability. See, for example, Burlington Industries, Inc v Milliken \& Co, 690 F2d 380,394 (4th Cir 1982) (noting that "joint and several liability [ ] has been the established doctrine of antitrust law for the better part of a century and which Congress has not seen fit to disapprove"); In re NASDAQ Market-Makers Antitrust Litigation, 169 FRD 493, 519 (S D NY 1996) (commenting that "[1]iability for antitrust violations is joint and several" in order to give plaintiffs an equal incentive to prove each defendants' participation in the alleged conspiracy).

83 See note 82.

84 See, for example, Brown v Cameron-Brown Co, 92 FRD 32, 39 (E D Va 1981) (finding that when thirty-six banks used an escrow account to generate income for themselves, the conspiracy exception allowed the plaintiff class to satisfy the $23(\mathrm{~b})(3)$ typicality requirement); Krehl $v$ Baskin-Robbins Ice Cream Co, 78 FRD 108, 115 (C D Cal 1978) (concluding that the typicality requirement was satisfied by a conspiracy to fix wholesale prices of ice cream). 
enforcement, which is a fundamental policy underlying the class action device.

\section{A. An Exception to Standing or Typicality}

Courts have failed to distinguish clearly whether the juridical link and concerted action exceptions are grounded in the Rule 23(a)(3) typicality requirement or in the Article III standing requirement. ${ }^{66}$ In determining whether juridical links or concerted actions are an exception to standing or to typicality, it is important to consider the underpinnings of standing and the Federal Rules. The Supreme Court has ruled that standing is an essential component of subject matter jurisdiction that cannot be waived. ${ }^{87}$ The Court has also clarified that the procedural device of a class action "adds nothing to the question of standing." " Therefore, a more plausible statement of the doctrine might be stated as follows: the juridical links doctrine provides two exceptions to Rule 23(a)(3) typicality, which generally requires that the representative plaintiff have a cause of action against each defendant, ${ }^{89}$ moreover, these exceptions may in some cases comport with the standing requirements of Article III.

Because a class action must satisfy both the minimum requirements of Rule 23 and Article III standing, determining the proper basis for analyzing the juridical links doctrine may depend to some degree on the order in which courts address the issues of class certification and standing. In Ortiz, the Supreme Court concluded that class certification issues "pertain to statutory standing, which may properly be treated before Article III standing." Thus, unless a plaintiff who lacks a cause of action against every defendant can satisfy the certifi-

85 See, for example, Amchem, 521 US at 617 (commenting that the "policy at the very core of the class action mechanism is to overcome the problem that small recoveries do not provide the incentive for any individual to bring a solo action prosecuting his or her rights"), quoting Mace v Van Ru Credit Corp, 109 F3d 338, 344 (7th Cir 1997).

86 Contrast Kohn v Mucia,776 F Supp 348,354-55 (N D Ill 1991) ("[J]uridical link doctrine essentially confers the standing of each individual class member on the class representative."), with Doe y Spokane and Inland Empire Blood Bank, 55 Wash App 106, 780 P2d 853, 860 n 6 (1989) ("[Unless] there is a juridical link among the defendants, the class representative's claim cannot possibly satisfy the typicality requirement.").

87 Lewis v Casey, 518 US 343,349 n 1 (1996).

88 Id at 357, quoting Simon v Eastern Kentucky Welfare Rights Organization, 426 US 26, 40 n 20 (1976).

89 See text accompanying note 26.

90527 US at 831. Compare Weiner v Bank of King of Prussia, 358 F Supp 684, 694 (E D Pa 1973) ("Standing to sue is an essential threshold which must be crossed before any determination as to class representation under Rule 23 can be made."); Newberg and Conte, 1 Newberg on Class Actions $\$ 3.19$ at 3-116 (cited in note 2) ("Standing is the threshold issue in any suit. If the individual plaintiff lacks standing, the court need never reach the class action issue."); Shafner, Note, 58 BU L Rev at 496 (cited in note 16) ("[A] named plaintiff in a class action must establish his standing to sue before he can even attempt to show that his claim is representative."). 
cation requirements of Rule 23, and, by extension, Rule 20(a) in cases involving individually joined defendants, the court will never reach the issue of Article III standing.

B. Exceptions Conflict with the Text of the Federal Rules

The Supreme Court has recently directed courts to adhere carefully to the text of the Federal Rules. particularly important in the context of class actions, where the ability to effect a binding judgment on absent class members requires careful attention to issues of procedural due process."

In Amchem, the Court ruled that district courts could only permit settlement of class actions that had first satisfied the mandatory criteria of Rule 23(a) and (b). The Court determined that this result was compelled by the careful balance of judicial policymaking embodied in the Federal Rules:

The text of a rule thus proposed and reviewed [by the Rules Advisory Committee, the Judicial Conference, Congress, and the Supreme Court] limits judicial inventiveness. Courts are not free to amend a rule outside the process Congress ordered, a process properly tuned to the instruction that rules of procedure "shall not abridge ... any substantive right. § 2072(b)."

Many applications of the juridical links doctrine cannot be reconciled with a careful analysis of the Federal Rules. These cases can be separated into two categories: bilateral class actions certified under Rule 23(b)(2); and class actions involving individually joined defendants which, despite the paucity of court analysis, have presumably been accomplished through the permissive joinder requirements of Rule 20(a).

1. Defendant classes under Rule 23(b)(2).

Rule 23 allows the representative party in a class action to "sue or be sued," thus explicitly contemplating both plaintiff and defendant classes. $^{95}$ However, neither the text of Rule 23 nor the Advisory Com-

91 See note 20 and accompanying text. See also Pavelic \& LeFlore $v$ Marvel Entertainment Group, 493 US 120, 126 (1989) (refusing to deviate from text of FRCP 11 and observing that "[o]ur task is to apply the text, not to improve upon it").

92 See Phillips Petroleum Co $v$ Shutts, 472 US 797, 811-12 (1985) (describing adequacy of representation, notice, and mandatory opt out provisions as minimum requirements of due process).

93521 US at $620-22$.

94 Id at 620 .

95 FRCP 23(a). 
mittee's Note provides any guidance for the situation in which a plaintiff class attempts to litigate claims against a defendant class.

The first applications of the juridical links doctrine were confined to the certification of defendant classes under Rule 23(b)(2). These cases were the "paradigm" juridical link situations, which sought injunctive or declaratory relief against a defendant class of government officials charged with the enforcement of an unlawful policy or statute. During the same period, Rule 23(b)(2) was also used to certify defendant classes in juridical links cases involving multiple employers tied together through an industry-wide collective bargaining agreement."

However, in 1980, the Fourth Circuit's decision in Paxman v Campbell $^{8}$ set forth a more textual interpretation of Rule 23(b)(2) that precluded the certification of bilateral class actions." In Paxman, two school teachers initiated a 23(b)(2) class action on behalf of all pregnant public school teachers in Virginia challenging the constitutionality of maternity leave policies enforced by school boards throughout the state. The court never addressed the issue of the juridical links doctrine, ruling instead that "the party opposing the class" language of Section 23(b)(2) could only be construed as allowing a single plaintiff or defendant to proceed against an opposing class. ${ }^{100} \mathrm{~A}$ few years later, the Seventh Circuit also rejected an expansive reading of this provision in Henson $v$ East Lincoln Township.

This narrow reading of Rule 23(b)(2) is now the prevailing view. ${ }^{102}$ In recent years, only the Second Circuit has continued to rely on this

96 See text accompanying notes 52-56.

97 See note 57 and accompanying text.

98612 F2d 848 (4th Cir 1980) (per curiam).

99 Id at 854.

100 Id.

101814 F2d 410, 414 (7th Cir 1987) (Posner) (rejecting a proposed Rule 23(b)(2) bilateral class action involving a single representative plaintiff against township officials throughout state; observing that "the ease and speed with which the Federal Rules of Civil Procedure can be amended by those whom Congress [has] entrusted ... should make federal judges hesitate to create new forms of judicial proceedings in the teeth of existing rules"). The Advisory Committee to the Judicial Conference recently considered changes to Rule 23(b)(2). See Civil Rules Advisory Committee, Minutes for April 18-19, 1996, 1996 WL 936787, *24 (voting 11-2 against proposed revision of Rule $23(\mathrm{~b})$ (2) that would clearly permit defendant classes).

102 See Thompson $v$ Board of Education of Romeo Community Schools, 709 F2d 1200, 1204 (6th Cir 1983) (following Paxman); Leer v Washington Education Association, 172 FRD 439, 452 (W D Wash 1997) (following Henson); National Union Fire Insurance Co v Midland Bancor, Inc, 158 FRD 681, 688 (D Kan 1994) (following Henson); Stewart v Winter, 87 FRD 760, 770 (N D Miss 1980) (following Paxman). Some commentators have continued to argue on the basis of policy and statutory construction that subsection (b)(2) permits bilateral class actions. See, for example, David H. Taylor, Defendant Class Actions Under Rule 23(b)(2): Resolving the Language Dilemma, 40 U Kan L Rev 77, 107-18 (1991) (arguing on basis of statutory construction that defendant classes are permitted under Rule 23(b)(2)). 
provision to certify defendant classes. ${ }^{103}$ Although not expressly directed at the juridical link or concerted action exceptions, the textual interpretation of 23(b)(2) has prevented their use in bilateral class actions, which had previously been the doctrine's most accepted application. ${ }^{104}$ Moreover, this situation cannot be changed by an increased reliance on Rule 23(b)(1), since the relatively narrow language and purpose of that provision are generally not amenable to multiple defendant class actions. ${ }^{105}$ Therefore, the only remaining category for defendant classes in a juridical links situation is Rule $23(\mathrm{~b})(3),{ }^{100}$ which permits defendants to exit the class under the opt out provision of subsection (c)(2). This application of the juridical links doctrine is examined under the proposed framework set forth in Part III.

\section{Individually joined defendants under Rule 20(a).}

Many courts that join defendants through the application of the juridical links doctrine fail to analyze the requirements of permissive joinder under Rule 20(a). Under Rule 20(a), two specific factors must be satisfied in order to join defendants in one legal proceeding: (1) a right to relief must be asserted against each defendant arising out of the same transaction or occurrence and (2) a question of law or fact must be common to all the parties. ${ }^{107}$ Like the class action device, Rule 20(a) is designed to promote judicial economy by reducing inconvenience, delay, and the need for multiple trials. ${ }^{\text {tho }}$ As a result, the "same transaction or occurrence" and "common question of law or fact" requirements are usually given a broad construction, ${ }^{109}$ and it is, therefore, conceivable that multiple defendants could meet these minimum thresholds.

103 See, for example, Monaco v Stone, 187 FRD 50, 64-68 (E D NY 1999) (certifying a defendant class of judges and a defendant class of sheriffs); Follette $v$ Vitanza, 658 F Supp 492, 50708 (N D NY 1987) (certifying a defendant class of all officials charged with enforcing income executions on judgment debtors).

104 See text accompanying notes 52-56.

105 See notes $30-31$ and accompanying text.

106 See Henson, 814 F2d at 417 (noting that despite limitations of 23(b)(2), "double class actions remain possible under (b)(3)").

107 See Desert Empire Bank v Insurance Co of North America, 623 F2d 1371, 1375 (9th Cir 1980); Mosley v General Motors Corp, 497 F2d 1330, 1333 (8th Cir 1974); Charles Alan Wright, Arthur R. Miller, and Mary Kay Kane, 7 Federal Practice and Procedure $\S 1653$ at 377-80 (West 2d ed 1986).

108 See notes 39 and 74 and accompanying text.

109 See United Mine Workers v Gibbs, 383 US 715, 724 (1966) ("Under the Rules, the impulse is toward entertaining the broadest possible scope of action consistent with fairness to the parties; joinder of claims, parties and remedies is strongly encouraged."); Wright, Miller, and Kane, 7 Federal Practice and Procedure $\S 1653$ at 389 (cited in note 107) (observing that transaction and common question requirements are not "rigid tests" and should be "read as broadly as possible whenever doing so is likely to promote judicial economy"). 
Yet under Amchem, policy goals cannot trump the explicit language of Rule 20(a). ${ }^{110}$ Consequently, if the representative plaintiff lacks a cause of action against each defendant, the representative is unable personally to assert a "right to relief" arising out of the same transaction or occurrence, ${ }^{111}$ which is a necessary precondition for bringing additional defendants into the litigation under Rule 20(a).

Despite this seemingly clear textual reading, some courts construe Rule 20(a)'s same transaction or occurrence requirements broadly and allow defendants to be joined even when the named plaintiff does not have a cause of action against them. For example, in Moore v Comfed Savings Bank, ${ }^{112}$ the court relied on a broad construction of the same transaction requirement to join various defendant banks who allegedly engaged in related violations of the Truth-inLending Act, even though the named plaintiff lacked a cause of action against each defendant. ${ }^{13}$ In these circumstances, however, courts fail to make an independent standing inquiry. ${ }^{1 / 4}$ As one district court noted, the decision in Moore "never addressed the issue of standing because the holding was based on the application of a procedural rule, which is distinct from a grant of jurisdiction and which cannot be used to expand the jurisdiction of the federal courts."115

\section{Exceptions Favor Plaintiffs' Counsel at the Expense of Procedural Fairness}

The case law on the juridical link and concerted action exceptions contains a complex and often incoherent merger of procedural and jurisdictional issues. One explanation for the expansion of the doctrine is that courts have uncritically relied on stare decisis to justify the doctrine and have incrementally extended it in cases where it might promote judicial economy. ${ }^{116}$ A second explanation is that plaintiffs' attorneys are likely to reap substantial strategic and financial benefits from an aggressive application of the doctrine's two exceptions. Because these benefits may come at the expense of procedural fairness for liti-

\footnotetext{
110521 US at 620.

111 FRCP 20(a).

112908 F2d 834 (11th Cir 1990).

113 Id at $837-40$.

114 See Part II.A.

115 Christiansen v Beneficial National Bank, 972 F Supp 681, 683 n 2 (S D Ga 1997). Compare FRCP 82 ("These rules shall not be construed to extend or limit the jurisdiction of the United States district courts.").

116 Consider Moore, 908 F2d at 838 (quoting the unpublished lower court opinion: "Other named plaintiffs could be supplied to match with each defendant but it would be unwieldy to do so. . . . No court would want to have 644 separate lawsuits"); In re Itel Securities Litigation, 89 FRD 104, 121 (N D Cal 1981) (applying doctrine because of "the great judicial convenience and economy which class certification would serve in the present case").
} 
gants, courts should look beyond the perceived gains of judicial efficiency in order to justify the continued use of the doctrine.

1. The increased leverage of defendant classes.

Courts have recognized that defendant classes raise special issues of due process. ${ }^{\mathfrak{1 1}}$ Although both defendant and plaintiff class actions limit the ability of class members to participate in the litigation process, the potential effect on each group is substantially different. As one district court summarized, "[T]he unnamed plaintiff stands to gain while the unnamed defendant stands to lose."118

Under the terms of Rule 23(b)(1) and 23(b)(2), members of the defendant class are bound to the outcome of the litigation although they receive neither notice of the lawsuit nor the ability to opt out. In contrast, these due process features are automatically triggered for 23(b)(3) defendant classes, which have generally made courts more willing to certify a bilateral class action under this subsection. ${ }^{119} \mathrm{Be}-$ cause 23(b)(3) also opens the door for any defendant who wants to exit the class, it is not surprising that plaintiffs' counsel have often tried to fashion their complaint in terms that can satisfy either subsections (b)(1) or (b)(2).

The Seventh Circuit's decision in Henson examined the serious issues of due process and jurisdiction raised by bilateral class actions in which the representative plaintiff lacks a cause of action against each defendant. In Henson, the representative plaintiff initiated a 23(b)(2) action against a defendant class of 770 townships in order to challenge welfare eligibility standards throughout the state of Ilinois. Because the requested litigation would affect parties statewide, the court was reluctant to apply Rule 23(b)(2), since this subsection would not provide defendant class members with notice of the lawsuit or the opportunity to opt out. ${ }^{121}$

117 Henson, 814 F2d at 414-15 (noting that 23(b)(2) class action creates severe problems of due process due to lack of notice and ability to opt out); DeAllaume v Perales, 110 FRD 299, 303 (S D NY 1986) (observing that a defendant class "raises due process issues not encountered in the context of a plaintiff class" and observing that courts mitigate this concern by requiring that named plaintiffs have a cause of action against each defendant.).

118 Thillens, Inc v Community Currency Exchange Association of Illinois, Inc, 97 FRD 668, 674 (N D Ill 1983).

119 See, for example, cases cited in note 65.

120 See, for example, Henson, 814 F2d at 413 (noting that plaintiffs' counsel purposefully sought 23(b)(2) certification in order to avoid defendant opt out); Hammond $v$ Hendrickson, 1986 US Dist LEXIS 22198, *32-33 (N D Ill) (arguing that "[i]n proposing certification of the defendant class under both Rule 23(b)(1) and 23(b)(3), plaintiff clearly seeks to avoid the 'opt out' provisions of 23(b)(3)"); Mudd v Busse, 68 FRD 522,530 (N D Ind 1975) (same).

121 Henson, $814 \mathrm{~F} 2 \mathrm{~d}$ at 415. 
The Henson court considered the limitations of class action litigation under Article III. Because each dispute within the proposed bilateral class action was ultimately between officials of each township and their residents, the court questioned whether there was an actual controversy between most members of the plaintiff and defendant classes. ${ }^{12}$ As the plaintiffs' counsel candidly acknowledged during oral argument, the defendant class was requested in order to alleviate the massive burden of locating a representative plaintiff in every jurisdiction. ${ }^{123}$ In rejecting the plaintiffs' proposal, the Seventh Circuit commented, "The double class action is a legislative or regulatory device for bringing about general compliance with law ... rather than an adjudicative device for resolving a dispute."124 Because the text of the rule suggested a more limited construction, ${ }^{125}$ the court was able to avoid a direct confrontation with Article III.

In addition to the issues of jurisdiction and due process, the Seventh Circuit also identified various procedural and statutory provisions that render a bilateral class action unnecessary. For example, in the context of federal civil rights claims, 42 USC $\$ 1988$ permits a plaintiff who has prevailed on the merits to receive reasonable attorneys' fees, which in turn provides defendants with a strong incentive to bring themselves into rapid compliance with relevant court decisions. ${ }^{126}$ In the event that a large number of separate class actions are filed that request essentially the same declaratory or injunctive relief, they could be brought into one court through 28 USC $\S 1407$, which authorizes the consolidation of multidistrict litigation involving common questions of fact. Thereafter, one test case could be adjudicated on the merits and "then the others resolved summarily."127

As the Henson court makes clear, a textual interpretation of Rule 23(b)(2) eliminates the use of bilateral class actions under Rule 23(b)(2) while also preserving the interests of both plaintiffs and defendants. Moreover, the court achieved this result without exceeding its jurisdiction under Article III.

2. The danger of using the doctrine as a freestanding method of joinder.

Because Rule 23(b)(3) is the class action device best suited for disputes involving monetary relief, ${ }^{125}$ a plaintiffs' attorney in a multiple

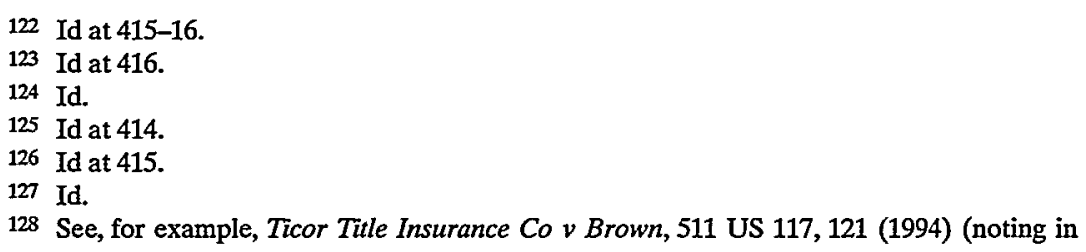


defendant class action has a strong incentive to avoid the 23(c)(2) opt out provision. If the representative plaintiff has a cause of action against each defendant, then the opt out provision may be avoided through permissive joinder under Rule 20(a). However, even if the representative plaintiff lacks a cause of action against each defendant, a plaintiffs' attorney may still be able to obtain joinder by relying on the confused and undertheorized case law that has applied the two exceptions.

Such a scenario is likely to unfold as follows: The plaintiffs' counsel drafts a complaint in which the defendants are arguably related through the concerted action or juridical link exceptions. Drawing on earlier precedent, he then argues that joinder is permitted even though the representative plaintiff lacks a valid cause of action against each defendant. A court considering this litigation posture may instinctively rely on the policy of judicial efficiency, which underlies the permissive joinder rule, without also considering the textual limitations on Rule 20(a) that may arise only in cases involving multiple defendant class actions. As long as the number of defendants is sufficiently small so as to avoid defendant class treatment, ${ }^{129}$ a plaintiffs' counsel may be able to create a 23(b)(3) joinder device that circumvents both the text of Rule 20(a) and the opt out of a Rule 23(b)(3) defendant class.

The plaintiffs' attorney's potential benefits from this strategy are substantial. Relieved of the search costs of locating additional plaintiffs who have been injured by each defendant, ${ }^{130}$ a plaintiffs' attorney simultaneously gains a larger potential recovery. In addition, settlement value may be significantly enhanced since the lack of a test case heightens uncertainty for defendants. Conversely, the aggregation of more claims may not necessarily ensure a larger recovery for the plaintiffs. This is because class actions are especially prone to agency problems. An attorney may be able to maximize his financial return and minimize his risk by agreeing to a quick settlement, though the interests of the class may be better served through more litigation. ${ }^{131}$ The

dicta that Rule 23(b)(3), because of the opt out provision, may be the only constitutionally permissible method of litigating class actions involving monetary relief).

129 For a description of the Rule 23(a)(1) numerosity requirement for defendant classes, see note 2.

130 Plaintiffs' attorneys may already possess strong incentives to invest minimal resources in a broad "portfolio" of class actions that may have a modest probability of success but nevertheless a substantial expected value. See John C. Coffee, Jr., Understanding the Plaintiff's Attorney: The Implications of Economic Theory for Private Enforcement of Law Through Class and Derivative Actions, 86 Colum L Rev 669,704-12 (1986).

131 See Jonathan R. Macey and Geoffrey P. Miller, The Plaintiffs' Attorney's Role in Class Action and Derivative Litigation: Economic Analysis and Recommendations for Reform, $58 \mathrm{U}$ Chi L Rev 1, 22-26 (1991) (observing that the current systems for reviewing attorneys' fees do not alter incentives to invest only minimal resources and then to settle early). 
insubstantial investment costs by the plaintiffs' attorney may also lower the acceptable settlement price, thus laying the groundwork for a collusive agreement between the plaintiffs' counsel and the defendants that provides substantial attorneys' fees and a modest class recovery in exchange for the res judicata protection of class certification.

One important distinction between individually joined defendants and a defendant class is that in the former each defendant is able personally to participate in the litigation. Although the requirements of commonality and typicality under Rule 23(a) might suggest a high degree of factual similarity among defendants related by a juridical link or concerted action, it may nevertheless be more difficult to present a defense against a representative plaintiff with whom the defendant neither injured nor dealt. Without the production of nominal plaintiffs injured by each defendant, the doctrine's two exceptions would essentially create a presumption of typicality that each defendant would be forced to rebut.

A better alternative would require a representative plaintiff to correspond with each named defendant. Although this may create logistical difficulties in locating additional injured parties, a corresponding loss in private law enforcement benefits would be unlikely. Following the adjudication of the first successful class action, other members of the plaintiffs' bar would be attracted to cases against defendants guilty of similar conduct. Moreover, the policy of judicial economy could be preserved in two ways. First, the outcome of the first case would provide a framework for settling claims against similar defendants. Second, parallel class actions involving similar facts and legal theories could still be consolidated through either Rule $42,{ }^{133}$ or the provisions on multidistrict litigation, 28 USC $\$ 1407 .{ }^{134}$

In summary, an aggressive application of the juridical links doctrine serves the interests of plaintiffs' attorneys at the alternate ex-

132 Id at 32, 48-49 (noting the "possibility of tradeoff between attorneys' fees and merits relief" in the settlement context). See also Ortiz, 527 US at 852 (acknowledging that "gigantic fees" may undermine arm's length bargaining).

133 FRCP 42(a) ("When actions involving a common question of law or fact are pending before the court, it may order a joint hearing or trial of any or all the matters in issue in the actions; it may order all the actions consolidated; and it may make such orders concerning proceedings therein as may tend to avoid unnecessary costs or delay.").

134 Cases that apply the juridical link exception to individually join subsidiaries of a common parent corporation, see note 59, also pose serious problems. Because state law recognizes corporations as separate legal entities with nearly the same rights as natural persons, see Robert Clark, Corporate Law $\$ 1.2$ at 17 (Little, Brown 1986), the juridical link of common ownership strips away the corporate veil without any showing of malfeaseance or substantial domination by the parent company. At least in federal court, this application of Rule 23 may be a violation of the Rules Enabling Act, which forbids a rule of procedure from "abridg[ing], enlarg[ing] or modify[ing] any substantive [state or federal] right." 28 USC \$2072(b). 
pense of either plaintiffs or defendants. With only speculative benefits of judicial economy, courts should rely on a textual reading of the Federal Rules, which would eliminate the doctrine as a joinder device and limit its future application to cases involving a Rule 23(b)(3) defendant class.

\section{A PROPOSED FRAMEWORK FOR THE JURIDICAL LINKS DOCTRINE}

Drawing on the Supreme Court's recent decisions in Amchem and Ortiz, this Comment proposes a two-part framework for analyzing multiple defendant class actions. First, courts should address all procedural requirements of the Federal Rules before addressing the issue of standing under Article III. Second, the inclusion of multiple defendants should be limited by the text of Rule 23 for defendant classes and Rule 20(a) for individually joined defendants.

When this framework is applied to cases involving the juridical links doctrine, only bilateral class actions certified under Rule 23(b)(3) can be reconciled with a careful application of the Federal Rules. As the following analysis suggests, Rule 23(b)(3) bilateral class actions are also more likely to survive scrutiny under Article III, even in cases in which the representative plaintiff lacks a cause of action against each member of the defendant class. Finally, in cases involving federal securities law, this more modest version of the doctrine may also promote judicial economy and private law enforcement without compromising procedural fairness for litigants.

\section{A. Applying the Framework to Multiple Defendant Class Actions}

The framework proposed by this Comment has two advantages for a court confronting a multiple defendant class action. First, addressing the Federal Rules before Article III standing clearly separates issues of procedure and jurisdiction, which will assist courts in avoiding the confusing merger of these concepts often found in the case law. ${ }^{135}$ Second, the textual interpretation of the Federal Rules effectively limits the scope of the juridical link and concerted action exceptions to Rule 23(a)(3) typicality. The permissibility of a multiple defendant class action therefore hinges more directly on the text of Rule 23(b) for defendant classes and Rule 20(a) for individually joined defendants.

135 This confusion extends beyond cases involving the juridical links doctrine. See Newberg and Conte, 1 Newberg on Class Actions $\$ 3.19$ at 3-112 (cited in note 2) (noting that conceptual similarity of standing and class representation has led to confusion within the courts); Note, Class Standing and the Class Representative, 94 Harv L Rev 1637,1642 (1981) (commenting that courts have "thoroughly conflated rule 23 and article III in application as well as in terminology"). 
1. Using the exceptions for 23(a)(3) typicality.

Returning to our example of the cable industry, plaintiff Doe only has a contract dispute with Acme Cable, challenging his late fees as unenforceable liquidated damages. If Doe attempts to proceed as a multiple defendant class action against Acme through Zydeco, his first hurdle is the Rule 23(a)(3) typicality requirement, which generally requires that the representative plaintiff have a cause of action against each defendant. ${ }^{136}$ However, if Doe is able to establish a juridical link ${ }^{137}$ or concerted action among the defendants, Doe's claim could still be typical of class members harmed by Acme through Zydeco. Assuming that Doe can also satisfy the commonality and adequacy of representation requirements of Rule 23(a), the analysis then considers how the twenty-six defendants will be added to the lawsuit: through defendant class treatment under Rule 23(b) or individual joinder under Rule 20(a).

2. Adding individually joined defendants.

In cases involving a plaintiff class action, the text of Rule 20(a) contains three requirements for joining additional defendants: (1) a representative plaintiff must assert a "right to relief" against each defendant (2) arising from "the same transaction, occurrence, or series of transactions or occurrences" (3) that involves "any question of law or fact common to all defendants." ${ }^{\text {"138 }}$ Because he only has a "right to relief" against Acme, Doe will not be able to include Beta through $\mathrm{Zy}$ deco in the litigation. The presence of a juridical link or concerted action among the defendants is limited to the issue of Rule 23(a)(3) typicality and cannot by itself accomplish joinder.

\section{Adding defendants through a Rule 23(b) defendant class.}

Under the three categories of Rule 23(b) class formation, plaintiff Doe will not be able to certify Acme through Zydeco as a Rule 23(b)(1) defendant class. The language of 23(b)(1)(A) requires that the risk of separate actions "would establish incompatible standards of conduct for the party opposing the class., ${ }^{, 39}$ However, in the instant

136 See cases cited in note 26.

137 To clarify this ambiguous term, this Comment adopts the following definition: A valid juridical link occurs where conduct among defendants "is standardized by a common link to an agreement, contract or enforced system which acts to standardize the factual underpinnings of the claims and to insure the assertion of defenses common to the class." Angel Music, Inc v ABC Sports, Inc, 112 FRD 70, 75, 77 (S D NY 1986) (setting forth a rule to distinguish copyright infringement dispute from cases involving the juridical link exception).

138 FCRP 20(a). This approach was developed in Part II.B.2.

139 FRCP 23(b)(1)(A). 
case, plaintiff Doe is the "party opposing the [defendant] class." Therefore, separate legal proceedings by other plaintiffs against Beta through Zydeco would have to expose Doe to the risk of "incompatible standards of conduct." Because Doe's legal obligations (to pay his late fees) only exist with regard to Acme, separate actions against other defendants have no binding effect on Doe.

Under Rule 23(b)(1)(B), class certification is appropriate only if "adjudications with respect to individual members of the [plaintiff and defendant] class ... would as a practical matter be dispositive of the interests of the other members ... or substantially impair or impede their ability to protect their interest." ${ }^{\text {,t1 }}$ Although the weight of precedent undoubtedly has an influence on subsequent cases (for example, a test case against Acme), courts are generally in agreement that stare decisis cannot serve as a basis for 23(b)(1)(B) class certification. ${ }^{142}$

As discussed in Part II.B.1, the "party opposing the class" language of Rule 23(b)(2) is phrased in the singular, ${ }^{143}$ which eliminates the possibility of a defendant class of Acme through Zydeco under this subsection. ${ }^{14}$ However, Doe may still be able to proceed against all twenty-six defendants under 23(b)(3), which is the broadest class action category. ${ }^{145}$ The text of the Rule imposes two requirements: "the court finds [1] that the questions of law or fact common to the members of the class predominate over any questions affecting only individual members, and [2] that a class action is superior to other available methods for a fair and efficient adjudication of the controversy." In our example, the nearly identical consumer contracts among Acme through Zydeco might satisfy the predominance prong, but the determination that a 23(b)(3) bilateral class action is "superior to other available methods" may depend on additional facts of the litigation."

140 See Robert E. Holo, Comment, Defendant Class Actions: The Failure of Rule 23 and a Proposed Solution, 38 UCLA L Rev 223, 235-38 (1990) (Because the "party opposing the [defendant] class" is the plaintiff, "inconsistent adjudications in defendant class actions almost never will establish incompatible standards of conduct for the plaintiff.").

141 FRCP 23(b)(1)(B).

142 See, for example, In re Catawba Indian Tribe, 973 F2d 1133, 1138 n 4 (4th Cir 1992) (noting that "it is settled that the possibility that an action will have either precedential or stare decisis effect on later cases is not sufficient to satisfy Rule $23(\mathrm{~b})(1)(B) ")$.

143 FRCP 23(b)(2). The text of Rule 23(b)(1)(A) also contains an identical limitation.

144 This textual interpretation of Rule $23(\mathrm{~b})(2)$ is the prevailing view within the federal courts. See text accompanying notes 98-104.

145 Shortly after the 1966 revision to Rule 23, the Reporter for the Rules Advisory Committee noted, "It will be found that cases satisfying (b)(1) or (b)(2) will also pass muster under (b)(3)." See Benjamin Kaplan, Continuing Work of the Civil Committee: 1966 Amendments of the Federal Rules of Civil Procedure (I), 81 Harv L Rev 356, 390 n 130 (1967).

146 FRCP 23(b)(3).

147 The text of Rule 23(b)(3) guides the inquiry into the predominance and superiority prongs: "[M]atters pertinent to the findings include: $(A)$ the interest of members of the class in individually controlling the prosecution or defense of separate actions; (B) the extent and nature 
This determination may also be affected by the willingness of Beta through Zydeco to participate in the litigation, since they would be permitted to exit the class under the $23(\mathrm{c})(2)$ opt out. $^{145}$

\section{B. Standing and Multiple Defendant Class Actions}

The "constitutional minimum" of standing has three elements: (1) the plaintiff must have suffered an invasion of a legally protected interest; (2) the alleged harm must be fairly traceable to the defendant's conduct; and (3) judicial intervention must be capable of redressing the alleged harm. ${ }^{149}$ When considering the Article III requirements of class actions, courts have traditionally focused on the individual standing of the representative plaintiff. For example, the Supreme Court has ruled that the procedural device of a class action "adds nothing to the question of standing," and that the named plaintiffs must allege a personal injury, rather than an injury suffered by members of the class, in order to satisfy the jurisdictional requirement of standing. ${ }^{\text {150 }}$

However, the Supreme Court's jurisprudence on the overlapping issues of class representation and standing has been set forth in cases in which the representative plaintiff could not establish standing with any defendant. Each of these failed class actions can be broken down into one of three categories. The representative plaintiff (1) relied exclusively on the rights of third parties in order to establish his own cause of action, ${ }^{151}$ (2) failed to allege the requisite personal injury that a court could redress through judicial intervention, ${ }^{152}$ or (3) articulated only generalized grievances shared by the public at large. ${ }^{153}$ However,

of any litigation concerning the controversy already commenced by or against members of the class; (C) the desirability or undesirability of concentrating the litigation of the claims in the particular forum; (D) the difficulties likely to be encountered in the management of a class action." FRCP 23(b)(3)(A)-(D).

148 This assumes that Doe and Acme serve as class representatives. As Part III.B suggests, certifying another defendant would create intractable problems under Article III.

149 Lujan v Defenders of Wildlife, 504 US 555, 560 (1992).

150 Lewis v Casey, 518 US 343, 357 (1996), quoting Simon v Eastern Kentucky Welfare Rights Organization, 426 US 26, 40 n 20 (1976). See also O'Shea $v$ Littleton, 414 US 488, 494 (1974) (holding that if named plaintiffs cannot establish case or controversy with defendants, none can seek relief on behalf of themselves or the class).

151 See, for example, Warth v Seldin, 422 US 490, 504-06 (1975) (holding that zoning ordinances affecting developers, which precluded the construction of affordable housing, were insufficient to confer standing on poor and minority plaintiffs).

152 See, for example, Simon, 426 US at 41-42 (holding that possible effects of tax code on hospitals' willingness to provide indigent healthcare were not injuries fairly traceable to conduct of the defendants).

153 See, for example, Allen $v$ Wright, 468 US 737,751 (1984) (holding that a challenge to IRS procedures for denying tax exemptions to racially discriminatory private schools was a generalized grievance insufficient to establish standing for nationwide class action filed by parents of black children). 
in our cable example, Doe will be able to set forth a justiciable "case or controversy" against Acme. In this respect, cases involving the two exceptions of the juridical links doctrine may present relatively novel issues of standing.

\section{Standing under Rule 20(a).}

In a multiple defendant class action in which a court rejects a textual analysis of Rule 20(a), the representative plaintiff who lacks a cause of action against each defendant will nevertheless face serious problems of standing. In our cable example, one possible theory for establishing standing is that Doe is asserting the rights of similarly situated parties within the plaintiff class who have been injured by Beta through Zydeco.

This approach finds some support in a line of Supreme Court decisions on mootness, where the injuries of the class are attributed to the lead plaintiff when his own claims no longer present a live controversy. ${ }^{1.4}$ As commentators have noted, the Supreme Court's jurisprudence on mootness and standing presents a significant conceptual tension. ${ }^{155}$ More recently, however, the Court has clarified that the mootness doctrine is intended to reach those transitory disputes capable of repetition yet evading review, but this does not eliminate the requirement that the class representative must possess standing at the time the lawsuit is filed. ${ }^{156}$ An additional problem with Doe relying on the rights of class members to establish standing with Beta through Zydeco is that it contradicts the Court's longstanding principle that a class action adds nothing to the question of standing.

\section{Standing under Rule 23(b).}

In a bilateral class action, inclusion of both plaintiffs and defendants is accomplished through Rule 23. One approach to the standing inquiry in this situation would require the court to focus exclusively

154 See, for example, United States Parole Commission v Geraghty, 445 US 388, 398 (1980) (holding that a named plaintiff may still litigate a class action despite the loss of personal stake if the claims are "capable of repetition, yet evading review"); Franks v Bowman Transportation Co, 424 US 747,755-56 (1976) (holding that a class action is constitutionally moot only if no controversy exists between the unnamed class members and defendant).

155 See Wood Hutchinson, $1983 \mathrm{~S} \mathrm{Ct} \mathrm{Rev} \mathrm{at} 495$ (cited in note 22) (referring to Supreme Court's recent mootness cases as "almost a complete perversion of Article III"); Note, 94 Harv L Rev at 1643-47 (cited in note 135) (arguing that the Court's jurisprudence on mootness is "diametrically opposed" to other cases based on standing).

156 See County of Riverside $v$ McLaughlin, 500 US 44, 51 (1991) (holding that ability to adjudicate a transitory dispute, such as a temporary jail detention without a prompt probable cause hearing, does not diminish the separate requirement that a representative plaintiff must possess standing at the time litigation is initiated).

157 See note 150 and accompanying text. 
on the relationship between the representatives of the plaintiff and defendant classes, since the requirements of Rule 23 presumably ensure a high degree of parallel interests among the members of each class. ${ }^{158}$ Therefore, in our cable example, Doe's alleged injury at the hands of Acme would be sufficient to establish standing against a defendant class.

It is important to note, however, that under the textual interpretation of the Federal Rules advocated by this Comment, a representative plaintiff who lacked a cause of action against each defendant would only be able to gain bilateral certification under Rule 23(b)(3). Although Rule 82 prohibits a rule of procedure from extending or limiting the jurisdiction of the federal courts, the Reporter for the 1966 Advisory Committee acknowledged that the revisions to Rule 23 would necessarily raise new issues of Article III jurisdiction:

New rule 23 alters the pattern of class actions; subsection (b)(3), in particular, is a new category deliberately created. Like other innovations from time to time introduced into the Civil Rules, those as to class actions change the total situation on which the statutes and theories regarding subject matter jurisdiction are brought to bear. ${ }^{159}$

Two features that distinguish Rule 23(b)(3) from the other categories of class actions are the mandatory notice and opt out provisions. ${ }^{160}$ In practical effect, a bilateral class action certified under this subsection invites (but does not compel) potential litigants to resolve parallel disputes in a single legal proceeding, presumably "achiev[ing] economies of time, effort, and expense, and promot[ing] uniformity of decision as to persons similarly situated," which is the Rule's intended purpose. $^{161}$ Therefore, a juridical link case brought as a 23(b)(3) bilateral class action may be reconcilable with the standing requirements of Article III.

\section{Policy Basis for a Limited Juridical Links Doctrine}

The combination of the juridical links doctrine and 23(b)(3) bilateral class actions has been limited to litigation under Sections 11

158 This is the method of analysis urged by one of the leading commentators on class actions. See Newberg and Conte, 1 Newberg on Class Actions $\$ 4.52$ at 4-204 to -205 (cited in note 2) (After demonstrating typicality and adequacy of representation, "it is inappropriate to consider whether the plaintiffs, (or the plaintiff class members in a bilateral class action,) have simultaneously demonstrated a personal injury with respect to every absent defendant class member under traditional standing tests."). .

159 Kaplan, 81 Harv L Rev at 399-400 (cited in note 145).

160 FRCP 23(c)(2)(A)-(B).

161 Proposed Rules, 39 FRD at 102-03 (cite in note 28). 
and 12(2) of the Securities Act of $1933 .^{162}$ This constrained application of the doctrine may promote judicial economy and private law enforcement benefits without compromising procedural fairness.

In these cases, Section 11 gives each plaintiff a cause of action against each participating underwriter when the stock registration statement contains a material misstatement or omission. ${ }^{163}$ However, the privity requirement of Section $12(2)$ restricts liability to parties who substantially participated in the sale of stock, which limits the representative plaintiff's claims under Section $12(2)$ to perhaps only one member of the defendant class. ${ }^{164}$ Because both claims involve the issue of misrepresentation in a common prospectus or registration statement, and the defendants are juridically linked by an underwriters' agreement, courts have been willing to permit a 23(b)(3) defendant class to adjudicate the fraud component common to both Sections 11 and $12(2) .{ }^{165}$ In the event that the representative defendant can prevail on this issue, no further litigation on the more particularized elements of Section 12(2) would be necessary. ${ }^{166}$

The willingness of both plaintiffs and defendants to remain in the litigation suggests a strong efficiency component, whereby plaintiffs can receive a fuller measure of their recovery (due to lower legal costs) and defendants can end all potential claims against them in a single legal proceeding. In at least some cases, the inevitability of litigation and the potential for economizing on legal costs mitigate the incentive for defendants to exit the class. ${ }^{167}$ Most likely this would occur in situations where the issue of liability is relatively certain, and the exercise of the opt out provision would likely result in higher legal costs. Because the class action device also serves to further the objectives of securities law by ensuring that more valid claims can be successfully litigated, ${ }^{168}$ the application of the juridical links exception to Section 12(2) claims is a sensible precedent that should be preserved.

162 See text accompanying notes $60-65$.

163 In re Gap Stores Securities Litigation, 79 FRD 283, 298 (N D Cal 1978).

164 See note 62 and accompanying text.

165 See cases cited in notes 60-63. These cases have all relied on Rule 23(c)(4)(A): "When appropriate an action may be brought or maintained as a class action with respect to particular issues."

166 See Endo v Albertine, 147 FRD 164, 171 (N D III 1993).

167 See Spencer Williams, Some Defendants Have Class: Reflections on Gap Securities Litigation, 89 FRD 287, 294-97 (1980) (trial judge in one of the initial 23(b)(3) bilateral class actions involving federal securities law commenting that only three of ninety-one defendants exercised the opt out provision).

168 See Blackie v Barrack, 524 F2d 891, 903 (9th Cir 1975) (observing that courts have upheld class actions in securities fraud "because of the substantial role that the deterrent effect of class actions plays in accomplishing the objectives of the securities laws"). 


\section{CONCLUSION}

Over the past three decades, the juridical link and concerted action exceptions have evolved from dicta in the Ninth Circuit's decision in La Mar to an amorphous and undertheorized body of case law that has dangerously merged procedural and jurisdictional issues. Drawing on the principles of class action jurisprudence set forth by the Supreme Court in Amchem and Ortiz, lower courts should consider the issues of class certification and Rule 20(a) joinder before turning to the issue of standing under Article III. Under this approach, courts would not be able to reconcile much of the juridical links case law with the requirements of Rule 23(b)(2) and Rule 20(a). However, for a narrow category of cases involving 23(b)(3) defendant classes, courts could employ the exceptions to serve the two policy objectives underlying the class action device: judicial economy and private law enforcement. In summary, courts should not view the juridical links doctrine as a joinder device, but as a test for ensuring Rule 23(a)(3) typicality for a plaintiff serving as class representative in a multiple defendant class action. 